\section{Análise macroscópica nas cabeceiras de drenagem da área urbana de Umuarama, região noroeste - Paraná/Brasil}

\begin{abstract}
Resumo: O acelerado processo de urbanização, aliado ao uso e ocupação podem desencadear graves alterações no ciclo hidrológico em bacias hidrográficas, principalmente nas áreas próximas às cabeceiras de drenagem. 0 município de Umuarama, a exemplo de outros municípios do Noroeste paranaense, vem, desde sua ocupação em meados do século XX, experimentando um rápido e desorganizado crescimento urbano, que tem promovido problemas em relação à cobertura vegetal tanto em áreas urbanas quanto em áreas de uso agrícola. Frente essas constatações, este trabalho teve como principal objetivo identificar e avaliar o nível de degradação nas cabeceiras de drenagem em área urbana de Umuarama, particularmente nos afluentes da alta bacia, localizada no córrego Pinhalzinho II. Foram avaliados diversos parâmetros tais como: cor da água, odor, lixo ao redor, materiais flutuantes, espumas, óleos, esgoto, preservação da vegetação, ocupação por animais domésticos, por humanos e a proximidade com edificações. A classificação baseou-se na Classificação do Grau de Impactos de Nascentes (2004) e no Guia de Avaliação da Qualidade das Águas (2004). De acordo com as análises, as nascentes apresentam-se degradadas, principalmente, pela presença de resíduos sólidos, esgoto doméstico e efluente industrial. Os resultados representam um sinal de alerta preocupante quanto à qualidade hídrica e, consequentemente, apontam para a necessidade de um monitoramento dos cursos hídricos, à proteção jurídica estabelecendo limites de apropriação e usos, e a conscientização ambiental da população quanto à produção e a destinação correta dos resíduos gerados.
\end{abstract}

\section{Analysis macroscopic headends drainage in the urban area of Umuarama, northwest region - Paraná / Brazil}

Abstract The accelerated process of urbanization, coupled with the use and occupancy can trigger serious changes in the hydrological cycle in river basins, especially in areas near the headwaters of drainage. The municipality of Umuarama, like other municipalities in the Northwest of Paraná, has, since its occupation in the mid-twentieth century experiencing rapid and disorganized urban growth, which has promoted issues in relation to vegetation cover in urban areas as in agricultural use. Front these findings, this study aimed to identify and assess the level of degradation in headwater drainage in urban areas of Umuarama, particularly in the tributaries of the upper basin, located in the stream Pinhalzinho II. We evaluated various parameters such as: water color, odor, litter around, floating materials, foams, oils, sewage, vegetation preservation, occupancy by domestic animals, by humans and proximity to buildings. The classification was based on the ranking of Degree of Impacts Springs (2004) and the Guide for Assessment of Water Quality (2004). According to the analysis, the sources present themselves degraded mainly by the presence of solid wastes, domestic sewage and industrial effluent. The results represent a warning sign of concern about the water quality and thus point to the need for monitoring of water resources, establishing limits to the legal protection of ownership and uses, and environmental awareness of the population regarding the production and proper disposal of waste generated.
Pedro França Junior, * Maria Estela Casale Dalla

*Doutorado em andamentoUNESP- PP. Mestre em Geografia - UEM

** Doutoranda em Geografia na UFPR Mestre em Geografia -UEM Maringá-PR

Palavras-chave:
Cabeceiras de drenagem;
Umuarama, Noroeste do
Paraná.
Key-Words: Headwater
drainage, Umuarama,
Northwest Paraná.




\title{
Introdução
}

O ciclo hidrológico é constituído por diferentes processos físicos, químicos e biológicos. Quando o homem interage nesse processo pode produzir grandes alterações modificando, drasticamente, o ciclo e trazendo consigo impactos significativos (muitas vezes de forma irreversível) ao próprio homem e à natureza.

Tucci (2005) salienta que a queda da qualidade de vida em áreas urbanas nos países em desenvolvimento é grande, principalmente, devido aos problemas ambientais gerados. Grande parte desses problemas é gerada devido à: falta de conhecimento generalizado da população sobre 0 assunto; concepção inadequada dos profissionais de engenharia para o planejamento e controle dos sistemas; visão setorizada de planejamento urbano; e falta de capacidade gerencial dos municípios.

Devido aos problemas citados acima, Tucci (2005) relata ainda que grande parte desses problemas geram impactos sobre as drenagens dentro do ambiente urbano.

\begin{abstract}
A drenagem urbana sofre fortes alterações devidas principalmente, à impermeabilização da superfície; a canalização do escoamento; poluição, devido à contaminação do ar, das superfícies urbanas e do material sólido disposto pela população. Esse processo apresenta grave impacto nos países em desenvolvimento, onde a urbanização e as obras de drenagem são realizadas de forma totalmente insustentável, abandonada pelos países desenvolvidos já há trinta anos (TUCCI, 2003).
\end{abstract}

Como visto acima, o inadequado processo de urbanização ao longo das últimas décadas tem desencadeado inúmeras alterações ambientais, principalmente nas áreas urbanas, localizadas próximas às cabeceiras de drenagem, tais como: desmoronamentos, assoreamento, poluição e/ou contaminação da água, desenvolvimento de processos erosivos, como sulcos, ravinas e voçorocas, promovendo alterações drásticas no ciclo hidrológico dessas bacias hidrográficas.

O município de Umuarama, a exemplo de outros municípios do Noroeste Paranaense, vem, desde sua formação em meados do século $\mathrm{XX}$, experimentando um rápido e desorganizado crescimento demográfico. A cobertura vegetal foi sendo retirada ao longo do tempo para que ocorresse a expansão de construções urbanas, da agricultura ou pecuária. Esse avanço da malha urbana impulsionou a deterioração e a poluição do ambiente de forma preocupante. A ocupação inadequada das áreas de cabeceira de drenagem, a canalização ou retificação de canais fluviais que cortam as áreas urbanas ou a má construção destas canalizações, é reflexo do pouco planejamento e a falta de conscientização da população com seus deveres de cidadania.

As pessoas que habitam, atualmente, os grandes centros, adoecem em maiores proporções das que vivem na zona rural, tais moléstias são originadas não apenas pela vida estressante das grandes cidades, mas também pela péssima qualidade de vida, as quais que se manifestam na qualidade das águas que drenam estes ambientes e no aumento de vetores de doenças que também fazem parte da presença desordenada do homem, principalmente, em regiões de fundos de vale ou até mesmo cabeceiras de drenagem, como se verificam neste caso.

Destaca-se ainda que: Frente às constatações, esse trabalho teve como principal objetivo identificar e diagnosticar o nível de degradação das cabeceiras de drenagem na área urbana de Umuarama, particularmente nos afluentes da montante na bacia do córrego Pinhalzinho II (Fig. 1). Para alcançar esse objetivo utilizou-se a metodologia proposta por Gomes et al (2005) baseada na Classificação do Grau de Impactos de Nascentes (2004) e no Guia de Avaliação da Qualidade das

Geografia Ensino \& Pesquisa, v. 17, n.1 p. 107-118, jan./abr. 2013

Análise macroscópica nas cabeceiras de drenagem da área urbana de Umuarama, Região noroeste - Paraná/Brasil
Águas (2004). Foram analisados 8 pontos no perímetro urbano e áreas no entorno da cidade, onde foram verificadas, cor da água, presença de vegetação, de lixo, ocupação por animais ou humanos, odor, lixo ao redor, proteção local, proximidades com residências e o tipo de área de inserção (propriedade privada ou pública).

Esse método contribuiu para uma melhor avaliação dos pontos analisados, auxiliando os gestores públicos no gerenciamento de áreas degradadas, e políticas públicas para sua revitalização. 


\section{Área de Estudo}

A área de estudo compreende as cabeceiras de drenagem na alta bacia do córrego Pinhalzinho II, as quais drenam a maior parte da área urbana da cidade de Umuarama que possui 100.676 habitantes (IBGE, 2011). O município localiza-se na região Noroeste do Paraná, cortada pelas rodovias: PR 323 e PR 468 (IBGE, 2011). O perímetro urbano ocupa cerca de $15 \mathrm{~km}^{2}$ dos $182 \mathrm{~km}^{2}$ da bacia do córrego Pinhalzinho II. A área urbana localiza-se nas coordenadas centrais de $23^{\circ} 47^{\prime} 55^{\prime \prime} \mathrm{S}$ de latitude e $53^{\circ} 18^{\prime} 48^{\prime \prime}$ W de longitude e as altitudes variam de 340 à 500 metros.

O município de Umuarama, bem como sua área urbana, surgiu a partir de diversos condicionantes históricos. Um dos fatores de grande relevância foi que a CMNP (Companhia Melhoramentos Norte do Paraná), no seu crescente desenvolvimento, atingiu a região denominada "Cruzeiro", onde se processou a colonização de uma área de 30 mil alqueires de propriedade de terceiros. Esse lote foi entregue à CMNP para colonização dessa forma surgiu a "Gleba Cruzeiro", sendo Umuarama, distrito do município de Cruzeiro do Oeste.

A fundação de Umuarama, segundo IBGE (2008), ocorreu no dia 26 de junho de 1955, na presença dos diretores da Companhia, além de centenas de personalidades convidadas que assinaram a Ata de Fundação de Umuarama.

Logo após esses fatos históricos, segundo documentos da Prefeitura de Umuarama (2008), o município passa a tornar-se um grande polo de produção de alimentos e instalação de indústrias, fatores que constituem fonte de renda e emprego. Devido sua infraestrutura urbana, a cidade passa ser fornecedora de serviços especializados como educação, saúde, técnica e cultura. Hoje, Umuarama desponta como polo regional da AMERIOS (Associação dos Municípios Entre Rios) e coordena essa instituição que abrange 32 municípios (Prefeitura Municipal de Umuarama, 2008).

Quanto aos aspectos físicos, os solos encontrados na região em sua maior abrangência são originados pela alteração das rochas sedimentares da Formação Caiuá. São solos de textura arenosa, que apresentam valores superiores a $70 \%$ de areia em sua composição, sendo extremamente friáveis desenvolvendo diversas formas de erosão (GASPARETTO, 1999; SOUZA 2001).

0 relevo corresponde à vertentes alongadas, com baixa declividade nos interflúvios e nas médias vertentes, mas apresenta declividades acentuadas próximo das drenagens, favorecendo 0 desenvolvimento de processos erosivos nesses locais (FRANÇA JUNIOR, 2010).

Anteriormente à chegada da população alóctone no início do século XX, essa região era recoberta em quase sua totalidade pela Floresta Estacional Semidecidual (MAACK, 2002). Atualmente, existem poucos fragmentos dessa cobertura vegetal, predominando no uso da terra as culturas de pastagens e lavouras temporárias (milho, soja), permanentes (Silvicultura), semipermanente (cana-de-açúcar) e secundariamente por áreas de florestas e mata ciliar (FRANÇA JUNIOR, 2010).

Figura 1- Localização da área de pesquisa e pontos de análise

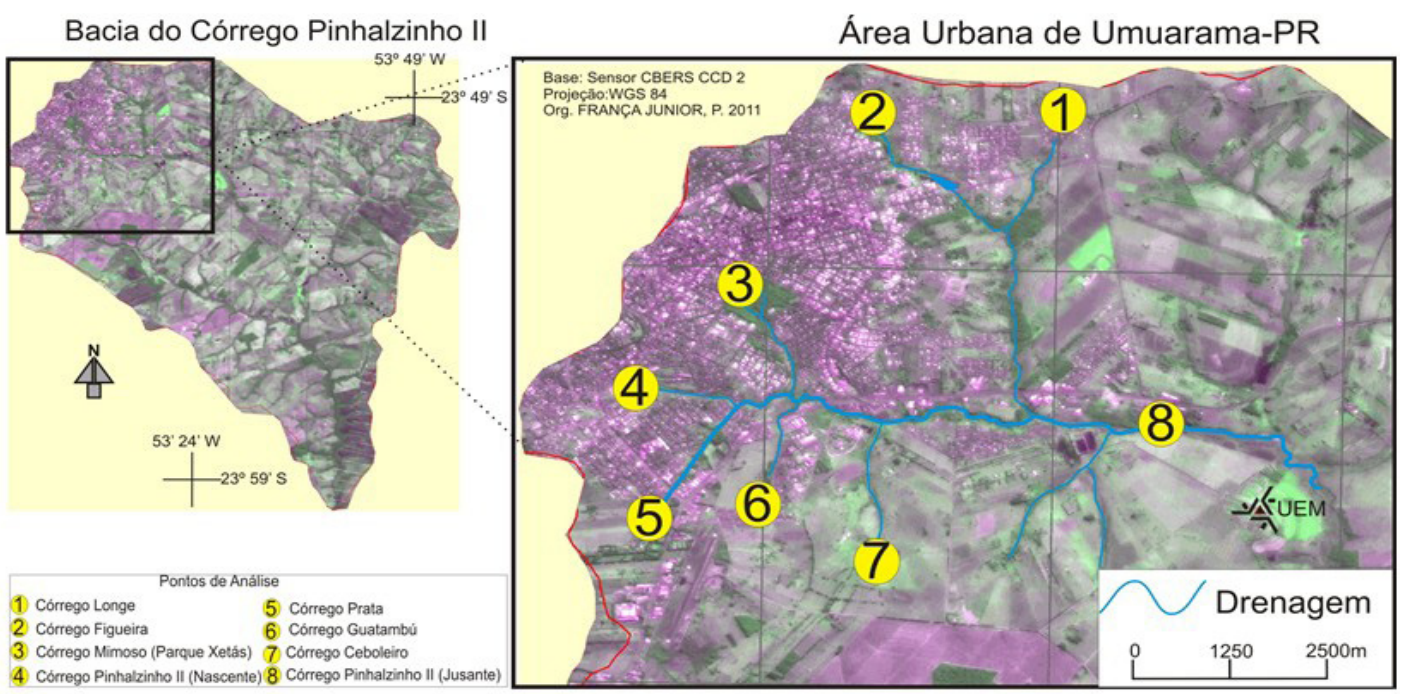

Geografia Ensino \& Pesquisa, v. 17, n.1 p. 107-118, jan./abr. 2013 


\section{Metodologia}

Essa pesquisa desenvolveu-se com base em levantamentos bibliográficos especíicos, ressaltando a importância de estudos ambientais em bacias hidrográficas, principalmente nas cabeceiras de drenagem, e com trabalho de campo para análise das características ambientais. Adotou-se a metodologia proposta por Gomes et al. (2005) baseada na Classificação do Grau de Impactos de Nascentes (2004) e no Guia de Avaliação da Qualidade das Águas (2004). Para observação e coleta dos dados utilizaram-se as variáveis que constam na tabela 1. Foi utilizado um raio de 50 metros de observação, conforme LEI 4771/1965, que obriga a preservação das cabeceiras. Cada variável possui 3 classes de análise conforme o grau de degradação.

Tabela 1- Quantificação das Variáveis

\begin{tabular}{|c|c|c|c|}
\hline Cor da água & (1) Escura & (2) Clara & (3) Transparente \\
\hline Odor & (1) Forte & (2) Fraco & (3) Sem \\
\hline Lixo ao redor & (1) Muito & (2) Pouco & (3) Sem \\
\hline Materiais flutuantes & (1) Muito & (2) pouco & (3) Sem \\
\hline Espumas & (1) Muita & (2) Pouca & (3) Sem \\
\hline Óleos & (1) Muito & (2) Pouca & (3) Sem \\
\hline Esgotos & (1) Doméstico & (2) Fluxo superficial & (3) Sem \\
\hline Vegetação (degradação) & (1) Alta & (2) Baixa & (3) Preservada \\
\hline $\begin{array}{l}\text { Uso por animais (exóti- } \\
\text { cos) }\end{array}$ & (1) Presença & (2) Apenas marcas & (3) Não detectado \\
\hline Uso por humanos & (1) Presença & (2) Apenas marcas & (3) Não detectado \\
\hline Proteção Local cercado & (1) Sem & $\begin{array}{l}\text { (2) Com proteção - com } \\
\text { acesso }\end{array}$ & $\begin{array}{l}\text { (3) Com proteção - } \\
\text { sem acesso }\end{array}$ \\
\hline $\begin{array}{l}\text { Proximidade clárea ur- } \\
\text { bana (metros) }\end{array}$ & (1) menos de 50 & (2) Entre 50 a 100 & (3) Mais de 100 \\
\hline Tipo de área de inserção & $\begin{array}{l}\text { (1) Ausente (Sem In- } \\
\text { formação) }\end{array}$ & (2) Propriedade privada & $\begin{array}{l}\text { (3) Parques ou áreas } \\
\text { protegidas }\end{array}$ \\
\hline
\end{tabular}

Fonte: Adaptado de Gomes et al. (2005)

Para análise dos resultados e classificação do grau de preservação utilizou-se a tabela 2, que pontua e classifica cada classe com o grau de preservação (ótima, boa, razoavel, ruim e péssima) e a pontuação verificada conforme somatória de resultados.

Tabela 2- Classificação quanto ao grau de preservação

\begin{tabular}{l|l|l} 
Classe & Grau de Preservação & Pontuação Final* $^{*}$ \\
\hline A & Ótima & Entre 37 a 39 pontos \\
\hline B & Boa & Entre 34 a 36 pontos \\
\hline C & Razoável & Entre 31 a 33 pontos \\
\hline D & Ruim & Entre 28 a 30 pontos \\
\hline E & Péssimo & Abaixo de 28 pontos
\end{tabular}

Geografia Ensino \& Pesquisa, v. 17, n.1 p. 107-118, jan./abr. 2013

Análise macroscópica nas cabeceiras de drenagem da área urbana de Umuarama, Região noroeste - Paraná/Brasil
(*) Resultado da somatória dos pontos obtidos da análise da tabela 1.

Fonte: Gomes et al. (2005)

As análises in loco foram desenvolvidas em março de 2009, no decorrer das pesquisas de campo do Grupo de Estudos Multidisciplinar do Meio Ambiente (GEMA), dentro do projeto Geoindi- 
cadores Ambientais de Bacias Hidrográficas Urbanas do Noroeste do Paraná, desenvolvido entre 2008 e 2010 (FRANÇA JUNIOR, 2010).

Analisou-se a qualidade das cabeceiras de drenagem na área urbana do município de Umuarama, na bacia do córrego Pinhalzinho II onde destacam-se: ponto 1- córrego Longe; ponto 2- córrego Figueira; ponto 3- córrego Mimoso (Parque Xetás); ponto 4- córrego Pinhalzinho II (nascente); ponto 5- córrego Prata; ponto 6- córrego Guatambú; ponto 7- córrego Ceboleiro. Os 7 primeiros são áreas de cabeceira de drenagem, enquanto o ponto 8- córrego Pinhalzinho II (jusante) esse é um receptor de todos os outros pontos (Fig. 1).

\section{Resultados e discussão}

Os resultados estão descritos qualitativamente por pontos de amostragem para o período de março de 2009, nos quais foram discutidas as características da avaliação ambiental conforme os parâmetros da tabela 1. Em seguida os parâmetros foram analisados quantitavamente de forma integrada, visando a classificação do grau de degradação de cada ponto avaliado (tabela 3).

\section{Ponto 1 - Córrego Longe}

De acordo com as observações, constatou que a água possui cor clara, sem odor, no entanto foi detectado fluxo de esgoto, com materiais flutuantes e espuma. No entorno há presença de lixos, como plásticos, móveis usados e entulhos de construção. Verificou-se também que a vegetação é composta por leucenas (Leucaena leucocephala') e gramíneas que servem de alimento ao gado. Esta espécie de vegetação foi plantada por moradores e autoridades públicas para a recuperação da área e impedir a erosão remontante que estava degradando o local. A erosão é proveniente do fluxo hídrico da galeria pluvial que é lançado à montante da nascente. A área próxima à cabeceira está cercada, sendo próxima à edificações (cerca de 50 metros).

\section{Ponto 2 - Córrego Figueira}

De acordo com as observações, a água apresentou cor transparente, sem odor, com aspecto de muito limpo, sem materiais flutuantes, nem presença de esgoto. Há pouco lixo, observando-se apenas entulhos e solos removidos no entorno (possível aterro para construções). O local é protegido em alguns lugares com vasta preservação das matas ciliares, o que não impede a invasão de pessoas, pois encontra-se próximo à residências (cerca de 40 metros).

A área encontra-se bem preservada na nascente, mas no entanto a 100 metros há jusante, esta foi represada para a formação de um lago artificial (lago Aratimbó). Esse lago foi construído para conter uma antiga voçoroca e servir como nível de base às galerias pluviais. Atualmente, encontra-se num processo intenso de assoreamento apresentando lixos e entulhos sobre o leito rochoso.

\section{Ponto 3 - Córrego Mimosa - (Parque Xetás)}

Nesse local a água apresentou cor escura, uma tonalidade cor cinza, provalvemente, devido aos esgostos domésticos, com odor muito forte e presença de materiais flutuantes, como: espuma e óleos. Há forte presença de lixo como, entulhos, plásticos, garrafas, pneus, e resíduos orgânicos (casca de coco, melancia, folhas). Por se localizar no centro de Umuarama, dentro de um parque ecológico sua preservação deveria ser primordial, no entanto, a área está em acelerado processo de degradação.

A galeria de esgoto está rompida, sendo despejada, juntamente, com as galerias de águas pluviais sobre esta nascente, formando uma voçoroca com mais de 4 metros de altura e 10 metros de largura. Devido ao fluxo hídrico intensificado o canal está erodindo a rocha mãe (arenito Caiuá), formando "marmitas" no leito e margens, modificando o talvegue.
${ }^{1}$ A espécie faz parte da lista de 100 mais agressivas espécies invasoras do planeta, da (IUCN, 2011 -União Internacional para a Conservação da Natureza)

2 Marmita; (Geomorfologia): Cavidades cilíndricas ou cônicas, verticais, presentes em rochas da calha de um rio. (Fonte: www.dicionario.pro.br/ dicionario/index.php/Marmita)

Geografia Ensino \& Pesquisa, v. 17, n.1 p. 107-118, jan./abr. 2013

França Junior, P. ; Villa, M. E. C.

ISSN 2236-4994 111 
${ }^{3}$ Quando introduzidas em novos ambientes, elas adaptam-se e ocupam agressivamente 0 espaço de espécies nativas, produzindo desequilibrios na biodiversidade, muitas vezes, irreversíveis (IUCN, 2011).
Geografia Ensino \& Pesquisa, v. 17, n.1 p. 107-118, jan./abr. 2013

Análise macroscópica nas cabeceiras de drenagem da área urbana de Umuarama, Região noroeste - Paraná/Brasil
A área possui proteção vegetal, porém sua composição está alterada, apresentando muitas espécies invasoras de porte baixo, misturado à Leucaena leucocephala ${ }^{2}$. Além da degradação do ambiente natural, observou-se também que o parque está degradado socialmente, segundo relato de moradores locais "este antes era lugar público utilizado para a prática da caminhada, mas virou lugar de vândalos e andarilhos, que utilizam o parque para consumo de drogas, assassinatos e assaltos". No ano de 2010 e 2011, já foram elaborados vários planos de reforma, mas ambos ainda estão no papel (PMU, 2010).

\section{Ponto 4 - Córrego Pinhalzinho II (nascente)}

Dos locais observados, esse possui a maior alteração antrópica. No local onde havia a nascente, formou-se uma voçoroca na década de 1990, cuja dimensão estava desestabilizando as moradias vizinhas e edificações públicas.

Para minimizar os impactos foi construído um estádio de futebol e um centro poliesportivo sobre esta nascente que teve suas águas drenadas por tubulações, sendo lançadas 150 metros abaixo numa caneleta concretada.

As características da água apontam alterações por despejo de esgoto doméstico, cheiro forte, e, no entorno, muito lixo. Verifica-se uma falta de conscientização por parte da população, pois além de jogarem lixos, entulhos, galhos de árvore, também ateiam fogo, queimando juntamente a vegetação ciliar que protege as margens do córrego.

O local encontra-se com acesso livre, sem proteção. As residências estão em torno de 50 metros de distância, sendo que algumas direcionam as tubulações de esgoto diretamente no canal, detectando assim uma área com alto grau de degradação.

\section{Ponto 5 - Córrego Prata}

Este local despertou atenção pelo fato da grande diferença de preservação entre a nascente e o canal em pequeno trecho, aproximadamente 100 metros.

A nascente possui água transparente, sem odor, com presença de vida aquática (girinos, pequenos peixes). Não há lixo, apenas matéria orgânica, devido a decomposição da vegetação. $A$ área encontra-se bem preservada na nascente com presença de vegetação ciliar.

Porém, como mencionado acima, no decorrer do canal observou-se forte degradação desencadeada pela urbanização em áreas impróprias (cerca de 20 metros do canal) de onde são lançados os esgotos domésticos a céu aberto, além da presença de animais domésticos (cavalos, cães). Nota-se que o canal está num processo intenso de assoreamento. Em relação à vegetação nativa, restam apenas alguns fragmentos.

Segundo relato de alguns moradores locais, o ponto que nascia o córrego era cerca de 200 metros acima do que ele está hoje, e esse local está sendo designado para ser loteado. Ainda segundo eles a nascente seria canalizada assim como foi feito com o córrego Pinhalzinho II.

\section{Ponto 6 - Córrego Guatambú}

Este córrego, está em área de um processo avançado de urbanização, situado a menos de 30 metros do canal. Possui água com cor clara, porém com presença de esgotos domésticos com odor, além de muito lixo, composto por estulhos, móveis usados, materiais flutuantes e espuma. A vegetação encontra-se praticamente toda devastada, restando apenas espécies invasoras e exóticas, como Santa Bárbara (Melia azedarach $L^{3}$.), Leucena (Leucaena leucocephala), e gramíneas.

Esse local também sofre com as queimadas provocadas pelos moradores, mostrando dessa forma a falta de conscientização e sensibilização quanto à necessidade de preservar 0 ambiente.

\section{Ponto 7 - Córrego Ceboleiro}

A nascente possui água limpa, sem odor e lixo, nem presença de esgoto e materiais flutuantes, mas logo após sua nascente já se encontra assoreado e suja devido ao pisoteio do gado e falta de vegetação ciliar para sua preservação. 
Essa área encontra-se na zona rural, numa propriedade privada, mas o entorno da nascente não está cercado, o que contribui ao pisoteio do gado e assoreamento do canal. Por estar próximo da área urbana, esse canal é degradado por indústrias (neste caso frigorífico) utilizando a água da nascente para seu abastecimento, e por meio de tubulações lança os flúidos gerados, que por sua vez são altamente poluentes (ricos em matéria orgânica) a jusante desse canal, o que vem contribuir para a poluição do córrego Pinhalzinho II.

\section{Ponto 8 - Córrego Pinhalzinho II (jusante)}

Esse ponto é receptor dos outros pontos identificados e analizados, localizando-se no curso médio do córrego Pinhalzinho II. Nessa região podemos vizualizar um rio com elevado grau de degradação. A coloração da água é escura, possui odor acentuado e lixo em suas margens, os quais são carreados pelas águas. Há também a presença de óleo e espuma na superfície.

Esse ponto é a jusante da estação de tratamento de esgoto, o qual depois de tratado é lançado neste canal, e próximo à uma tinturaria de jeans, que despeja no canal seus efluentes tingidos de azul. Além disso, observam-se próximo desse ponto, um processo de erosão marginal e intenso assoreamento do leito.

Segundo França Junior (2010), o assoreamento do canal foi decorrente dos processos erosivos instalados a partir do início da urbanização da cidade, onde foram remobilizadas grandes quantidades de sedimento e, posteriomente, a deposição destes em planícies fluviais. A vegetação é quase ínfima, restando apenas alguns fragmentos preservados. A pastagem tomou conta das planícies de inundação, com forte pisoteio de gado.

\section{Quantificação dos Parâmetros Analisados}

Os dados obtidos com as análises foram sistematizados na tabela 3, e a somatória comparada com a tabela 2, para determinação do grau de preservação dos recursos hídricos da área urbana de Umuarama, particularmente nas cabeceiras na alta bacia do córrego Pinhalzinho II. As fotos que correspondem aos pontos podem ser visualizadas na figura 2 .

Tabela 3- Resultados das variáveis

\begin{tabular}{|c|c|c|c|c|c|c|c|c|c|}
\hline \multirow[b]{2}{*}{ Variáveis } & \multicolumn{8}{|c|}{ Pontos analisados } & \\
\hline & 1 & 2 & 3 & 4 & 5 & 6 & 7 & 8 & \\
\hline Cor da água & 2 & 3 & 1 & 2 & 3 & 2 & 2 & 1 & \\
\hline Odor & 3 & 3 & 1 & 1 & 3 & 2 & 3 & 1 & \\
\hline Lixo ao redor & 1 & 2 & 1 & 1 & 3 & 1 & 3 & 1 & \\
\hline Materiais flutuantes & 2 & 3 & 2 & 2 & 3 & 2 & 3 & 2 & \\
\hline Espumas & 3 & 3 & 2 & 3 & 3 & 2 & 3 & 2 & \\
\hline Òleos & 3 & 3 & 2 & 3 & 3 & 3 & 3 & 2 & \\
\hline Esgoto & 1 & 3 & 1 & 1 & 3 & 1 & 3 & 1 & \\
\hline Vegetação (preservação) & 2 & 3 & 3 & 1 & 3 & 1 & 3 & 1 & \\
\hline Uso por animais & 2 & 3 & 3 & 1 & 3 & 3 & 1 & 1 & \\
\hline Uso por humanos & 2 & 3 & 2 & 2 & 2 & 2 & 2 & 2 & \\
\hline Proteção Local & 2 & 3 & 2 & 1 & 2 & 1 & 2 & 2 & \\
\hline $\begin{array}{l}\text { Proximidade com residência /estabe- } \\
\text { lecimento }\end{array}$ & 2 & 1 & 2 & 2 & 1 & 1 & 3 & 2 & $\begin{array}{l}\text { Geografia Ensino \& Pesquisa, v. 17, n.1 } \\
\text { p. 107-118, jan.labr. } 2013\end{array}$ \\
\hline Tipo de área de inserção & 2 & 3 & 2 & 1 & 2 & 2 & 2 & 2 & \\
\hline Total & 27 & 36 & 25 & 21 & 34 & 23 & 33 & 20 & França Junior, P. ; Villa, M. E. C. \\
\hline
\end{tabular}


Figura 2- Fotos dos pontos de análises

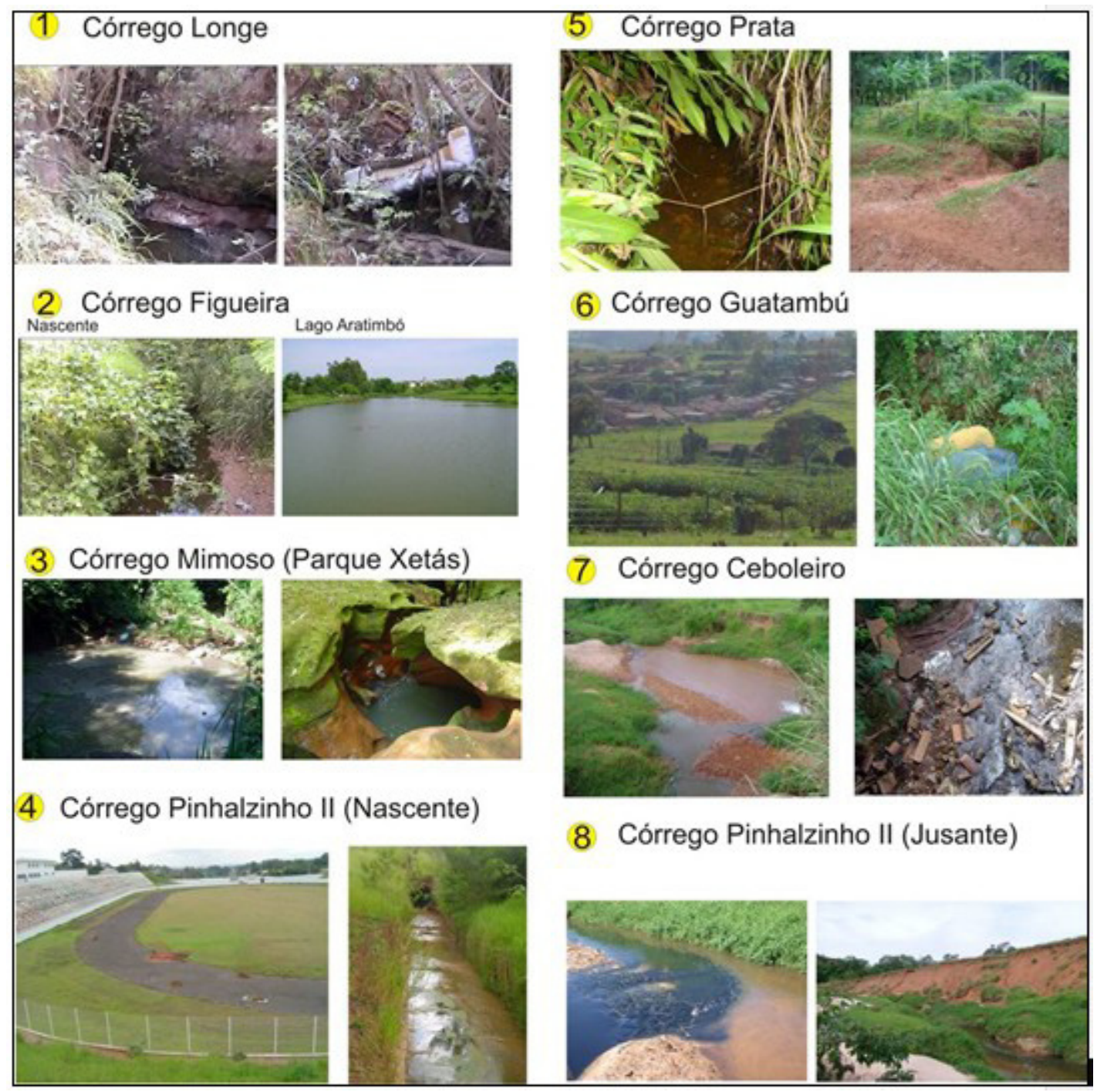

Fonte: Organizado pelos autores $-03 / 2009$

Observa-se que mais de $60 \%$ (pontos: 1, 3, 4, 6, 8) das áreas analisadas estão em péssimas condições de preservação pertencendo a classe E. Apenas 25 \% (pontos: 5 e 7) estão em boas condições, estando na classe $\mathrm{D}$. Apenas um ponto (2) está em condição razoável, pertencendo a classe $C$, ou seja, nenhum ponto obteve as classes ótima $(A)$ e boa (b).

A tabela 3 mostra que $25 \%$ dos pontos possuem água com cor escura, e que mais de 35 $\%$ apresenta cheiro forte das águas. Constatou-se também que $60 \%$ possuem proteção (áreas cercadas), no entanto de fácil acesso para moradores e animais. Além disso, há presença de lixo e esgoto doméstico. Quase $40 \%$ pontos analisados possuem cobertura vegetal em alta degradação, estando essas a menos de 50 metros de distância de áreas residenciais edificadas.

Os resultados mostraram que as nascentes e seus respectivos canais de drenagem da área

Geografia Ensino \& Pesquisa, v. 17, n.1 p. 107-118, jan./abr. 2013

Análise macroscópica nas cabeceiras de drenagem da área urbana de Umuarama, Região noroeste - Paraná/Brasil urbana do município de Umuarama, apresentam um elevado grau de degradação ambiental, refletido no aspecto da água e nos processos erosivos, devidos principalmente à falta de cobertura vegetal, ocupações irregulares, falta de fiscalização e investimentos públicos. Por mais que alguns pontos estejam afastados da mancha urbana, os mesmos ainda sofrem a influência da urbanização. A figura 3 mostra os pontos com as cores correspondentes conforme cada classe. 
Figura 3- Classificação das cabeceiras de dreangem conforme a classificação da tabela 2

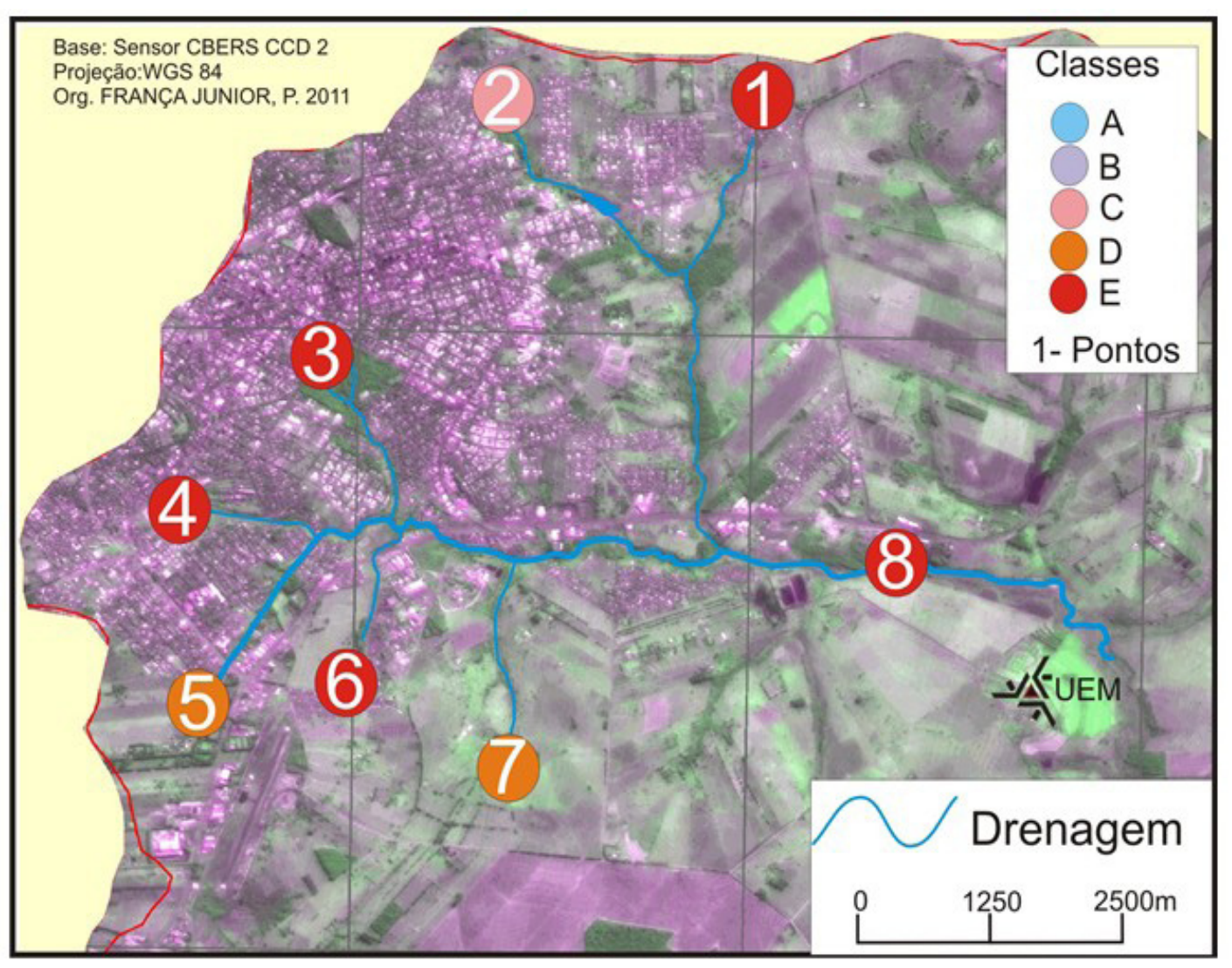

\section{Limitações da pesquisa}

Essa técnica, assim como outras, possuem limitações, pois ela é de caráter visual, não integra dados coletados e analisados em laboratório, depende dos lugares analisados, do grau de entendimento do avaliador e do objetivo da pesquisa. Porém, ela foi utilizada em outros trabalhos, o que reforça, que esse tipo de análise, reflete a qualidade ambiental integrada da área estudada.

\section{Considerações finais}

Os resultados representam um sinal de alerta preocupante quanto à qualidade hídrica $\mathrm{e}$, consequentemente, apontam à necessidade de um monitoramento e gerenciamento da bacia hidrográfica. A proximidade com as residências e falta de proteção, facilita o contato da população com estas áreas desprotegidas intensificando a degradação nas nascentes. A maioria dos pontos analisados $(60 \%)$ encontram-se em péssimas condicões de preservação, sendo que o restante apresenta-se em condições razoáveis.

Além disso, observou-se a falta de faixas ou placas que indicassem que estas áreas correspondiam a nascentes, as quais deveriam ser nominadas como um elemento da natureza, assim como são nominados os bosques, lagos e grandes rios. Portanto, é necessária a aplicação das Leis Ambientais pelos gestores (BRASIL, 2012) para recuperação e preservação dessas áreas, além de práticas de educação ambiental que salientem a população da importância da preservação das nascentes e dos canais que drenam não apenas a área urbana, mas todo o município.

Deve-se destacar que no novo Código Florestal Brasileiro de 2012, na Seção I que trata da delimitação das Áreas de Preservação Permanente no parágrafo IV, cita-se que as áreas no entorno das nascentes e dos olhos d'água perenes, qualquer que seja sua situação topográfica, devem ser

Geografia Ensino \& Pesquisa, v. 17, n.1 p. 107-118, jan./abr. 2013

França Junior, P. ; Villa, M. E. C.

ISSN 2236-4994

| 115 
preservadas no raio mínimo de 50 (cinquenta) metros. Ou seja, a lei determina que essas áreas são frágeis e necessitam de preservação, o que identificou-se nessa pesquisa é um descaso com a lei, necessitando assim de sua aplicação imediata.

Para continuidade nas pesquisas, complementando essa,necessitam-se, urgentemente, de estudos mais detalhados, como a realização de análises físico-químicas nos cursos d'água, como a pesquisa desenvolvida por Villa (2010) nesta região, além da quantificação das causas e consequências dos impactos sofridos pela área de drenagem e sobretudo da intensificação de medidas para conter a destruição e proteger as áreas consideradas de preservação permanente.

\section{Agradecimentos}

À Fundação Araucária por meio do convênio 319/2007 e ao CNPq/Processo $n^{\circ}$ 473253/2007- Projeto: Análise de indicadores geoambientais nas bacias hidrográficas da região Noroeste do Paraná: bases para a recuperação e gestão ambiental;

Aos Professores do GEMA - Grupo de Estudos Multidisciplinares do Ambiente por meio do Professor Dr. Nelson V. L. Gasparetto, pelo apoio nas pesquisas de campo e logística; e à Professora Dra Marta Luzia de Souza, pelas correções e orientações no decorrer das pesquisas.

\section{Referências}

BRASIL, LEI No 12.651. Código Florestal Brasileiro. Diário oficial da União. DE 25 DE MAIO DE 2012. Brasilia-DF

Classificação do grau de impactos de nascente. 2004. Disponível: http://snirh.inag. pt/. Acesso em março de 2009.

FRANÇA JUNIOR, P. Análise do uso e ocupação da bacia do córrego Pinhalzinho Il utilizando geoindicadores, Umuarama-PR, 1970-2009. Maringá, 2010. Dissertação de mestrado. Programa de Pós-graduação em Geografia, Universidade Estadual de Maringá-PR.

GASPARETTO, N. L. As formações superficiais do Noroeste do Paraná e sua relação com o arenito Caiuá. São Paulo, 1999.185p. Tese de doutorado em Geoquímica e Geotectônica. Instituto de Geociências, Universidade de São Paulo.

GOMES, P. M; MELO, C; VALE, V. S. Avaliação dos impactos ambientais em nascentes na cidade de Uberlândia - MG: análise macroscópica. Sociedade \& Natureza, Uberlândia, 17 (32):103120, jun. 2005.

Guia de Avaliação da Qualidade das Águas. 2004. Disponível em: http://www.rededasaguas.org.brl . Acesso em março de 2009.

IBGE/BIBLIOTECA disponível em: http://biblioteca.ibge.gov.br/ acesso em dezembro de 2008.

Geografia Ensino \& Pesquisa, v. 17, n.1 p. 107-118, jan./abr. 2013

Análise macroscópica nas cabeceiras de drenagem da área urbana de Umuarama, Região noroeste - Paraná/Brasil
IBGE/CIDADES disponível em: http://www.ibge.gov.br/cidadesat/topwindow acesso em janeiro de 2011.

IUCN- UNIÃO INTERNACIONAL DA CONVERVAÇÃO DA NATUREZA disponível em http://www.iucn.org/ acesso em 12 de dezembro de 2011.

MAACK, R. Geografia física do estado do Paraná. $3^{\circ}$ ed. Curitiba: Imprensa Oficial. 2002. 
PMU - Prefeitura Municipal de Umuarama (2008) disponível em: http://www.umuarama.com.br/ acesso em dezembro de 2008.

SOUZA, M. L. Proposta de um sistema de classificação de feições erosivas voltados a estudos de procedimentos de analises de decisões quanto a medidas corretivas, mitigadoras e preventivas: aplicação no município de Umuarama (PR). Rio Claro: 2001 284f. Tese de doutorado - Universidade Estadual Paulista, Instituto de Geociências e Ciências exatas.

TUCCI, C. E. M. Parâmetros do Hidrograma Unitário para bacias urbanas brasileiras. Revista Brasileira de Recursos Hídricos. Porto Alegre - RS, 2003. Vol 8 nº 2 pags. 195-199.

Programa de drenagem sustentável: apoio ao desenvolvimento do manejo de águas pluviais urbanas. Versão 2.0. Brasília: Ministério das Cidades, 2005.

VELOSO, H.P. Sistema fitogeográfico. In Manual técnico da vegetação brasileira. Instituto Brasileiro de Geografia e Estatística, Rio de Janeiro. 1992.p. 9-38.

VILLA, M. E. C. D. Fontes de poluição da bacia do córrego Pinhalzinho II em Umuarama - PR. Maringá, 2010. Dissertação de mestrado. Programa de Pós-graduação em Geografia, Universidade Estadual de Maringá-PR.

\section{Correspondência:}

Pedro França Junior- Universidade Estadual do Centro-Oeste, Setor de Ciências Agrárias e Ambientais- Departamento de Geografia. Rua Simeão Camargo Varela de Sá n. 03. Vila Cascavel. 85040-080 - Guarapuava, PR - Brasil

E-mail: francapedro2000@yahoo.com.br

Recebido em 30 de julho de 2012.

Revisado pelo autor em 18 de fevereiro de 2013.

Aceito para publicação em 24 de março de 2013. 